\title{
HABITAT SELECTION AND ITS EFFECT ON REPRODUCTIVE OUTPUT IN THE HERRING GULL IN NEWFOUNDLAND ${ }^{1}$
}

\author{
RAYMond PierotTi ${ }^{2}$ \\ Department of Biology, Dalhousie University, \\ Halifax, Nova Scotia, Canada B3H 4JI
}

\begin{abstract}
The breeding biology of the Herring Gull (Larus argentatus) was studied on Great Island, Newfoundland for part of the 1976 breeding season, and for two succeeding complete breeding seasons (1977 and 1978). Gulls nesting in three different habitats (designated puffin, rocky, and meadow) were compared with regard to several reproductive parameters. More pairs were found to nest in rocky habitat, and fewer pairs were found to nest in puffin habitat, than would be expected from a random distribution. In 1977, a year of low food availability, pairs in rocky habitat laid and hatched eggs significantly earlier than in the other two habitats. In 1978, when food was more abundant, gulls in rocky habitat laid heavier eggs than their counterparts in the other habitats. In both 1977 and 1978 , chicks from rocky habitat grew at the fastest rate and were heavier than chicks in the other habitats. Finally, results of an experiment to test the egg-production capacity of females demonstrated that female gulls in rocky habitat were capable of producing significantly more eggs than their counterparts in meadow and puffin habitats.

Despite the apparently better condition of gulls in rocky habitat, however, Herring Gull pairs in puffin habitat fledged as many chicks per nest as pairs in rocky habitat in 1977 and 1978, and even fledged more chicks in 1976. In all $3 \mathrm{yr}$ of study, gulls in meadow habitat fledged the fewest chicks per nest. Within habitats, chick survival was strongly correlated with early laying dates and high rates of growth. However, there was also a large residual effect which was probably due to differences in the habitats.

These differences are probably due to crowding and socially induced mortality in rocky habitat, and to the presence of predatory Great Black-backed Gulls in meadow habitat. The results support the theoretical models for habitat selection and dispersion developed by Fretwell and Lucas (1970), which suggest that increasing density in a preferred habitat can create a situation whereby fitness may actually be greater in a less-preferred habitat.
\end{abstract}

Key words: breeding biology; habitat selection; Herring Gull; Larus argentatus; Newfoundland; seabird; territoriality.

\section{INTRODUCTION}

The adaptive significance of habitat selection within species of vertebrates is often discussed but rarely demonstrated in the ecological literature. A recent review of the subject indicates that this is because, "estimates of survival and reproductive success for one species in more than one habitat can be difficult to obtain because animals are unlikely to occur naturally in less-preferred habitats if preferred ones are available ..." (Partridge 1978).

There may also be a problem involved in attributing differences in breeding success between habitats to the habitat alone. Partridge (1978) also suggests that, "if there is competition for preferred habitats, and some animals are forced into less-preferred habitats, it may be that those animals which succeed in obtaining access to preferred habitats are fitter. Any comparison between their success and that of the animals in less-preferred habitats will be confounded by this original difference in fitness."

Theoretical treatments of habitat selection present

\footnotetext{
${ }^{1}$ Manuscript received 30 May 1980; revised 1 June 1981; accepted 8 July 1981; final version received 12 August 1981 .

2 Present address: Pierotti and Associates, 307 Columbia St., Santa Cruz, California 95060 USA.
}

a possible resolution to this problem. Brown (1969) indicated that there will always be a fitness cost associated with breeding in a habitat that is less than optimal. Fretwell and Lucas (1970), using a more analytical approach, suggested that suitability of a habitat should decline with increasing density. Therefore, if the preferred habitat is nearly saturated, individuals should have the option of attempting to settle in the preferred habitat, or of settling in a less-preferred habitat with a lower density. In this context, I define a "preferred" habitat as one in which individuals will settle, provided that the habitat is not saturated. An "optimal" habitat, in contrast, is one in which individuals produce the most offspring which survive to reproduce. A preferred habitat may also be optimal, but if the preferred habitat is saturated, this is not necessarily the case. If adult mortality or breeding success are density dependent, an individual could leave as many or more offspring by settling in the lesspreferred habitat. This result was observed among tits in Holland (Kluyver and Tinbergen 1953). However, an investigation by Nettleship (1972) lends support to Brown's (1969) suggestion of a fitness cost associated with breeding in less-preferred habitats.

These questions must be resolved by investigating the quality of individuals nesting in different habitats, 
the costs associated with nesting in these habitats, and the number and condition of offspring achieved in the different habitats. By individual quality, I mean the ability to accumulate and mobilize energy, and to win at intraspecific competition for whatever resource or resources may be limiting. Quality is differentiated from fitness in this case because if an individual is breeding in a saturated but preferred habitat, it may leave fewer offspring than other individuals breeding in an unsaturated but less-preferred habitat.

Gulls are good organisms on which to conduct an investigation of this type. They settle in small, easily defined territories that are used only for breeding. The food supply, as in nearly all seabirds, is separate from the breeding colony (Ashmole 1971, Nettleship 1972), even though some food may be obtained on the territory when gulls breed in close association with other species.

The Herring Gull (Larus argentatus) breeds in at least three major, distinguishable habitats on Great Island, Newfoundland: (1) exposed, rocky, marine terraces, (2) grassy meadows atop the island, and (3) turf-covered maritime slopes where Atlantic Puffins (Fratercula arctica) breed in large numbers. This last habitat is rare for gulls, as Atlantic Puffins occur in only a few large isolated colonies, whereas Herring Gulls nest throughout the North Atlantic. This study was designed to test the hypothesis that differences exist among birds nesting in the three habitats, and that the differences could be demonstrated by examining clutch size, egg size, timing of laying, hatching success, chick hatching masses and growth rates, and production of fledged young.

\section{STudy Site}

Great Island is located $\approx 2 \mathrm{~km}$ off the southeastern shore of the Avalon Peninsula in the Witless Bay Seabird Sanctuary, at latitude $47^{\circ} 11^{\prime} N$., longitude $52^{\circ} 46^{\prime} \mathrm{W}$. Great Island has the largest breeding colony of Atlantic Puffins (Fratercula arctica) in the western Atlantic, numbering some 148000 pairs (Brown et al. 1975). It also has some 2100 pairs of Herring Gulls (Larus argentatus) (see Results), and seven other species of seabird breed on the island as well.

For a more complete description of Great Island, its seabird fauna, topography, and vegetation, see Nettleship (1972). Of the six major habitat types described by Nettleship (1972), Herring Gulls were found to nest in substantial numbers in four (grassy hummocks, $R \boldsymbol{u}$ bus and grass meadows, bare bedrock, and exposed peat). A few pairs also nested in the eroded meadow, and no gulls were observed to nest in the areas dominated by black spruce (Picea mariana), balsam fir (Abies balsamea), and heavy shrubbery. Herring Gulls also did not nest in the meadow areas that were dominated by Rubus.

In 1976, I established seven study plots in areas used by Herring Gulls for nesting. Two of these were in grass-hummock habitat on maritime slopes (puffin habitat), three were in grassy meadows, one in bare bedrock, and one (not illustrated) in an area that contained both large boulders and some grassy area between rocks where a few puffins nested (Fig. 1). Exposed peat habitat was not monitored because it was very fragile. In 1977, three additional study plots were established, one in puffin habitat and two in bare bedrock. The boulder habitat plot was divided: one part became one of the new rocky study plots; the other part, where puffins nested, was added to an adjacent puffin habitat study plot. These nine study plots were monitored in both 1977 and 1978.

\section{Methods and Materials \\ Gull census and nest distribution}

The gull population on Great Island was censused on 24 June 1976. This census was carried out following the method described by Nettleship (1976:section 4.2.1) by walking systematically through the entire colony and marking each nest with spray paint to avoid omissions or double counts.

The total area of Great Island used for nesting by gulls was determined by projecting a topographical map of the island on a grid and then counting the number of squares on the grid in each habitat type. Area occupied by each habitat was then calculated using the total number of squares (each square represented $\left.900 \mathrm{~m}^{2}\right)$.

\section{Timing of reproduction and egg dimensions}

Field work began in early June 1976, and continued during the full breeding seasons (May through August) of 1977 and 1978. As I arrived after egg-laying during the 1976 season, data were not collected on timing of reproduction and dimensions of the eggs. I was, however, able to estimate clutch sizes by noting the number of eggs or chicks present, although this would fail to account for eggs or chicks which disappeared before my arrival. Study plots were checked daily throughout May and early June until egg-laying was completed. From this time until mid-July, plots were checked every 3rd d in 1977 and every other day in 1978. The location of each nest was marked when the first egg was laid, and the nest was checked every time the plot was visited. Dates of laying, pipping, and hatching were recorded for each egg.

Each egg examined was weighed and measured within $48 \mathrm{~h}$ of laying. Length and breadth were measured to the nearest $0.1 \mathrm{~mm}$ using Vernier calipers. Egg volume was calculated according to the method described by Harris (1964) (see Table 4). Mass was determined by placing the egg in a cloth bag of known mass, and then weighing the bag and egg on a 100-g or 300-g Pesola scale. Eggs were then marked using 
TABLE 1. Distribution of gulls (Herring and Great Blackbacked) by habitat on Great Island in 1976.

\begin{tabular}{lcccc}
\hline \hline & $\begin{array}{c}\text { Percent } \\
\text { of total } \\
\text { habitat } \\
\text { (total }=\end{array}$ & $\begin{array}{c}\text { Percent } \\
\text { of gull } \\
\text { pairs in } \\
\text { habitat } \\
\text { (total }=\end{array}$ & $\begin{array}{c}\text { Number } \\
\text { of pairs } \\
\text { Habitat }\end{array}$ & $\begin{array}{c}\text { Expected } \\
\text { number } \\
\text { of pairs } \\
\text { if random } \\
\text { in habitat }\end{array}$ \\
\hline Puffin & 627.7 & $500 \mathrm{~m}^{2}$ ) & 2144 pairs) \\
Meadow & 26.7 & 27.3 & 1083 & 1364 \\
Rocky & 9.6 & 22.2 & 476 & 572 \\
\hline
\end{tabular}

${ }^{*} \chi^{2}=412.07, \mathrm{df}=2 P<.001$.

Statistical tests used were either from Sokal and Rohlf (1969) or SPSS. When testing the null hypothesis that one set of data was not significantly different from another set of data, I accepted a two-tailed probability of $<.1$ as significant.

\section{RESUlts}

\section{Gull census and nest distribution}

In 1976, I counted 2144 gull nests on Great Island, of which $\approx 50$ were nests of Great Black-backed Gulls (Larus marinus), so there were $\approx 2100$ pairs of Herring Gulls (Larus argentatus) on Great Island at that time. Of these, slightly more than half of this total were found in puffin habitat, with the remainder divided between rocky and meadow habitat (Table 1). However, puffin habitat made up nearly two-thirds of the available nesting habitat, compared with $<10 \%$ of the total being rocky habitat, which was confined to the periphery of the southern portion of the island (Nettleship 1972: Fig. 2). Therefore, puffin habitat had significantly fewer pairs than would be expected if distribution were random, and rocky habitat had significantly more pairs.

Rocky habitat is spatially more heterogeneous than puffin or meadow habitat, so there was more space available than is apparent from simple calculations of percentage areas. However, nests were more clumped in rocky habitat (see below), so more birds appear to use less space in rocky habitat than in the other two habitats. Also, much of the habitat included in rocky habitat was unused by gulls because it either consisted of sheer cliffs where gulls could not nest, or was within the splash zone of storm waves. In puffin and meadow habitat, all areas included were potentially available for nesting.

\section{Timing of reproduction}

In 1977, the first Herring Gull egg was laid on 8 May. Egg-laying in rocky habitat was initiated and completed significantly earlier than in either puffin or meadow habitat (Table 2). Median dates of egg-laying (and hatching) in all three habitats were very similar to mean dates in both 1977 and 1978.

The timing of hatching (and subsequently, of fledg- ing) showed a similar pattern (Table 3 ). The first chick hatched (from the first egg laid) on 7 June, which gave an incubation period (for that egg) of $30 \mathrm{~d}$. In 1977, the mean hatching date of first-laid eggs in rocky habitat was $3 \mathrm{~d}$ earlier than the mean hatching date of first eggs in meadow habitat and $5 \mathrm{~d}$ before that of first-laid eggs in puffin habitat. Second-laid eggs in all habitats hatched at approximately the same time as first-laid eggs (Table 3), because the brood patches of the parents do not become fully vascularized and defeathered until the second egg is laid, so that incubation is less efficient earlier (Beer 1962, R. Pierotti, personal observation). The mean date of hatching of third eggs was only $2 \mathrm{~d}$ earlier in rocky habitat than in the other two habitats. As there were significant differences between the hatching dates of first and second eggs in puffin and meadow habitats, this is an apparent anomaly. This resulted because pairs initiating clutches late in the season in puffin habitat only laid one or two eggs and thus had no effect on the mean laying date of third eggs. Overall, average incubation period was 28-29 d for first eggs and $26 \mathrm{~d}$ for second and third eggs in all three habitats in 1977.

In 1978, the overall pattern changed markedly (Tables 2 and 3). There were no significant differences in either laying or hatching dates among the three habitats. Furthermore, fewer pairs in meadow habitat had three egg clutches, so these pairs had no effect on mean laying date of third eggs. Mean hatching dates were between 19 and 21 June for all eggs in all habitats. This resulted because many third eggs laid early in the season hatched before subsequently laid first and second eggs. Incubation periods were $29 \mathrm{~d}$ for first eggs, $27 \mathrm{~d}$ for second eggs, and $26 \mathrm{~d}$ for third eggs.

\section{Clutch size and egg dimensions}

In 1976 , mean clutch size in rocky habitat was $2.44 \pm 0.72$, in puffin habitat $2.27 \pm 0.73$, and in meadow $2.16 \pm 0.72$. Clutch size in meadow was significantly lower $\left(\chi^{2}=5.38\right.$, df $\left.=4, .01<P<.05\right)$ than in rocky habitat. In 1977, a similar pattern emerged $\left(\chi^{2}=9.70\right.$, df $\left.=4, .01<P<.05\right)$ and puffin habitat had a slightly higher mean $(2.72 \pm 0.54)$ than rocky habitat $(2.65 \pm 0.56)$, and meadow $(2.51 \pm 0.63)$. In 1978 , puffin habitat again had the highest mean clutch size $(2.67 \pm 0.61)$ compared with rocky $(2.60 \pm 0.62)$, and meadow $(2.51 \pm 0.73)\left(\chi^{2}=6.55, \mathrm{df}=4\right.$, $.01<P<.05)$. Fig. 2 shows the frequency distribution of clutch sizes in all three years.

There were only a few significant differences in egg dimensions among the three habitats (Table 4). In 1977 , birds in rocky habitat laid longer first eggs than did birds in the other habitats, and in 1978, birds in rocky habitat laid heavier first and second eggs than their counterparts in the other habitats. Overall, eggs were larger in all dimensions in all habitats in 1978 than in 1977 (Table 4). 
TABLE 2. Mean laying dates of Herring Gull eggs on Great Island (number of days after 1 May).

\begin{tabular}{lllll}
\hline \hline & & \multicolumn{3}{c}{ Laying date (days after 1 May) $(n)$} \\
\cline { 3 - 4 } Year & Habitat & \multicolumn{1}{c}{ First egg $\dagger$} & Second egg $\dagger$ & Third egg $\neq$ \\
\hline 1977 & Rocky (R) & $18.8 \pm 6.5(108) \S^{*}$ & $21.0 \pm 6.5(104))^{1 *}$ & $22.8 \pm 6.5(74) \S^{*}$ \\
& Puffin (P) & $23.2 \pm 7.3(120)$ & $25.6 \pm 7.5(111)$ & $26.1 \pm 5.9(70)$ \\
1978 & Meadow (M) & $21.6 \pm 7.3(90)$ & $24.0 \pm 7.3(85)$ & $25.1 \pm 7.7(53)$ \\
& Rocky (R) & $21.8 \pm 7.2(117)$ & $23.9 \pm 7.2(110)$ & $24.8 \pm 6.2(77)$ \\
& Puffin (P) & $22.2 \pm 6.7(134)$ & $23.8 \pm 6.3(127)$ & $26.5 \pm 6.5(102)$ \\
& Meadow (M) & $22.5 \pm 8.4(89)$ & $24.1 \pm 8.0(80)$ & $23.3 \pm 6.2(54)$ \\
\hline
\end{tabular}

† Differences among habitats significant at .05 level (ANOVA) in 1977.

‡ Differences among habitats significant at .01 level (ANOVA) in 1977.

$\S \mathrm{R}<\mathrm{P}, \mathrm{M}$ at .01 level (Student-Newman-Keuls test [SNK]).

" $\mathbf{R}<\mathbf{M}$ at .05 level, $\mathbf{R}<\mathbf{P}$ at .01 level (SNK).

* Difference between years significant at .05 level ( $t$ test).

Hatching success, chick growth, and fledging success

In 1976, gulls in puffin habitat hatched $1.79 \pm 0.99$ eggs per nest compared with $1.86 \pm 0.95$ eggs per nest in rocky habitat, and birds in meadow habitat had the lowest number of eggs hatched per nest $(1.69 \pm 0.96)$. These differences were significant $\left(\chi^{2}=6.32\right.$, df $=6$, $.01<P<.05$ ) (Fig. 3).

In 1977, there were no differences in the number of eggs hatched per nest between gulls in rocky and puffin habitat (rocky $=2.09 \pm 0.94$; puffin $=1.99 \pm$ 1.00). In both areas a higher number of eggs hatched per nest than hatched in meadow habitat $(1.69 \pm 1.07)$ $\left(\chi^{2}=9.84\right.$, df $\left.=6, .01<P<.05\right)$. In 1978, birds in puffin habitat hatched more eggs per nest $(2.10 \pm 0.99)$ than did birds in rocky and meadow habitat (rocky = $1.93 \pm 1.07$; meadow $=1.79 \pm 1.06$ ), although once again comparison with the meadow habitat contributed the largest part of the $\chi^{2}$ value $\left(\chi^{2}=7.17, \mathrm{df}=\right.$ $6, .01<P<.05$ ).

Masses of chicks in rocky habitat were higher than those of their counterparts in other habitats (Tables 5, 6 , and 7). In 1977, the differences were significant only for hatching masses and for chicks $>20 \mathrm{~d}$ old, regard- less of their position in the hatching sequence. In 1978, however, chicks in rocky habitat were heavier throughout the entire period. The only time when chicks from rocky habitat were significantly lighter than chicks in another habitat was at $5 \mathrm{~d}$ of age in 1977. In general, chicks from puffin habitat were heavier than chicks from meadow habitat, although the differences were only occasionally significant.

Chicks in rocky habitat grew at the fastest rate in both 1977 and 1978 (Table 8). In 1977, chicks in puffin habitat grew at a faster rate than chicks in meadow habitat. However, in 1978, chicks in meadow habitat grew at a faster rate than those in puffin habitat, but the difference was not significant. In general, chicks in all habitats were heavier at any given age and grew at a faster rate in 1978 than in 1977.

With regard to fledging success, gulls nesting in puffin habitat in 1976 were more productive than their counterparts in other habitats (puffin $=1.58 \pm 0.75$ chicks per nest; rocky $=1.32 \pm 0.81$ chicks per nest; meadow $=1.03 \pm 0.89$ chicks per nest; $\chi^{2}=19.32$, df $=6, .001<P<.01$ ) (Fig. 4). The difference between pairs nesting in rocky and meadow habitats was also significant using comparisonwise df $\left(\chi^{2}=8.86\right.$,

TABLE 3. Mean hatching dates of Herring Gull eggs on Great Island (number of days after 1 June).

\begin{tabular}{|c|c|c|c|c|}
\hline \multirow[b]{2}{*}{ Year } & \multirow[b]{2}{*}{ Habitat } & \multicolumn{3}{|c|}{ Days to hatching $(n)$} \\
\hline & & Chick from first egg $\dagger$ & Chick from second egg $\dagger$ & Chick from third egg $\ddagger \S$ \\
\hline 1977 & $\begin{array}{l}\text { Rocky } \\
\text { Puffin } \\
\text { Meadow }\end{array}$ & $\begin{array}{l}16.5 \pm 6.4(86) \S^{*} \\
21.4 \pm 7.2(86) \\
18.9 \pm 6.1(64)^{\|}\end{array}$ & $\begin{array}{l}16.1 \pm 5.8(88) \Upsilon^{*} \\
21.7 \pm 7.8(90) \\
19.2 \pm 6.3(64)^{\|}\end{array}$ & $\begin{array}{l}17.7 \pm 6.2(52) \S^{*} \\
20.7 \pm 5.6(52) \\
21.1 \pm 7.6(34)\end{array}$ \\
\hline 1978 & $\begin{array}{l}\text { Rocky } \\
\text { Puffin } \\
\text { Meadow }\end{array}$ & $\begin{array}{l}20.3 \pm 7.1(85) \\
19.9 \pm 7.0(111) \\
19.2 \pm 8.1(64)\end{array}$ & $\begin{array}{l}20.8 \pm 6.5(84) \\
19.8 \pm 5.8(104) \\
19.9 \pm 7.2(62)\end{array}$ & $\begin{array}{l}19.3 \pm 6.3(58) \\
20.3 \pm 5.7(74) \\
19.1 \pm 6.2(37)\end{array}$ \\
\hline
\end{tabular}

$\uparrow$ Differences among habitats significant at .025 level in 1977 (ANOVA)

$¥$ Differences among habitats significant at .05 level in 1977 (ANOVA).

$\S \mathrm{R}<\mathrm{P}, \mathrm{M}$ at .01 level (SNK).

ๆ $\mathrm{R}<\mathrm{M}$ at .05 level, $\mathrm{R}<\mathrm{P}$ at .01 level (SNK).

" $\mathrm{M}<\mathrm{P}$ at .05 level (SNK).

* Difference between years $P<.05$ ( $t$ test). 
TABLE 7. Masses in grams of chicks from third-laid eggs. Number of chicks in parentheses.

\begin{tabular}{|c|c|c|c|c|c|c|c|c|}
\hline Habitat & Year & Day $0 \dagger$ & Day 5 & Day $10 \ddagger$ & Day 15 & Day $20 \ddagger$ & Day 25 & Day 30 \\
\hline \multirow[t]{2}{*}{ Rocky } & 1977 & $\begin{array}{c}61.7 \pm 7.28 \\
(50)\end{array}$ & $\begin{array}{c}100.1 \pm 18.1^{*} \\
(26)\end{array}$ & $\begin{array}{c}238.3 \pm 48.8^{11 *} \\
(23)\end{array}$ & $\begin{array}{l}383.1 \pm 70.6 \\
(22)\end{array}$ & $\begin{array}{c}583.2 \pm 75.38^{*} \\
(19)\end{array}$ & $\begin{array}{c}753.2 \pm 104.1^{*} \\
(19)\end{array}$ & $\begin{array}{c}853.4 \pm 90.28 * \\
(14)\end{array}$ \\
\hline & 1978 & $\begin{array}{c}63.9 \pm 5.18 \\
(56)\end{array}$ & $\begin{array}{c}120.6 \pm 26.4 \\
(24)\end{array}$ & $\begin{array}{c}270.8 \pm 57.5 \\
(20)\end{array}$ & $\begin{array}{c}445.0 \pm 65.2 \\
\quad(20)\end{array}$ & $\begin{array}{c}635.9 \pm 91.4 \\
(16)\end{array}$ & $\begin{array}{c}812.0 \pm 106.6 \\
(18)\end{array}$ & $\begin{array}{c}985.5 \pm 88.8 \pi \\
(11)\end{array}$ \\
\hline \multirow[t]{2}{*}{ Puffin } & 1977 & $\begin{array}{c}57.9 \pm 5.5 \\
(51)\end{array}$ & $\begin{array}{c}104.4 \pm 20.3^{*} \\
(28)\end{array}$ & $\begin{array}{c}233.9 \pm 39.7 " \\
(24)\end{array}$ & $\begin{array}{l}359.5 \pm 66.5 \\
(25)\end{array}$ & $\begin{array}{c}497.3 \pm 84.7^{*} \\
(23)\end{array}$ & $\begin{array}{c}681.3 \pm 102.7^{*} \\
(22)\end{array}$ & $\begin{array}{c}776.3 \pm 83.6^{*} \\
(13)\end{array}$ \\
\hline & 1978 & $\begin{array}{c}60.0 \pm 5.8 \\
(49)\end{array}$ & $\begin{array}{c}120.4 \pm 19.2 \\
(32)\end{array}$ & $\begin{array}{c}256.5 \pm 43.9 \\
(27)\end{array}$ & $\begin{array}{l}414.1 \pm 74.5 \\
\quad(23)\end{array}$ & $\begin{array}{c}591.3 \pm 87.2 \\
(26)\end{array}$ & $\begin{array}{c}729.1 \pm 100.8 \\
(22)\end{array}$ & $\begin{array}{c}913.3 \pm 85.7 \\
(12)\end{array}$ \\
\hline \multirow[t]{2}{*}{ Meadow } & 1977 & $\begin{array}{c}57.1 \pm 6.3 \\
(34)\end{array}$ & $\begin{array}{c}103.3 \pm 17.9 \\
(22)\end{array}$ & $\begin{array}{c}195.4 \pm 42.1^{*} \\
(20)\end{array}$ & $\begin{array}{c}346.9 \pm 71.3 \\
(18)\end{array}$ & $\begin{array}{c}503.8 \pm 78.8^{*} \\
(18)\end{array}$ & $\begin{array}{c}679.0 \pm 105.4^{*} \\
(16)\end{array}$ & $\begin{array}{c}759.4 \pm 75.3^{*} \\
(10)\end{array}$ \\
\hline & 1978 & $\begin{array}{c}59.6 \pm 7.1 \\
\quad(33)\end{array}$ & $\begin{array}{c}103.8 \pm 21.6 \\
(17)\end{array}$ & $\begin{array}{c}246.8 \pm 38.3 \\
(18)\end{array}$ & $\begin{array}{l}417.8 \pm 76.2 \\
\quad(16)\end{array}$ & $\begin{array}{c}560.7 \pm 72.6 \\
(15)\end{array}$ & $\begin{array}{c}761.5 \pm 109.2 \\
(15)\end{array}$ & $\begin{array}{c}952.5 \pm 61.2 \\
\text { (11) }\end{array}$ \\
\hline
\end{tabular}

$\dagger$ Differences among habitats significant at .05 level 1977 and 1978 (ANOVA).

¥ Differences among habitats significant at .1 level 1977 (ANOVA).

$\$ \mathrm{R}>\mathrm{P}, \mathrm{M}$ at .05 level (SNK).

" $\mathbf{R}, \mathbf{P}>\mathbf{M}$ at .05 level (SNK).

If $\mathbf{R}>\mathbf{P}$ at .05 level $(\mathrm{SNK})$

* Difference between years $P<.05$ ( $t$ test).

Thirty-three new pairs of Herring Gulls in puffin habitat and 14 new pairs in meadow habitat established nests in study plots during the $3 \mathrm{yr}$ of this study, compared with only three new pairs in rocky habitat. Number of nests increased $27 \%$ in $2 \mathrm{yr}$ in the two puffin habitat study plots monitored since 1976, and $12 \%$ in $1 \mathrm{yr}$ in the puffin habitat study plot added in 1977. During the same period, the number of nests in the study plots in rocky habitat remained essentially constant.

Nests in rocky habitat had a significantly higher mean shelter rating (Table 10) than nests in the other habitats (Table 9). Rocky habitat is spatially more heterogeneous, and this allows the nests to be located more closely. The relationship between spatial heterogeneity, nest shelter, and nest spacing appeared to be consistent throughout all study plots. Other than in rocky habitat, the study plot with highest mean shelter rating and lowest internest distance was a plot in meadow habitat which contained a number of dead spruce trees. In fact, a highly significant negative correlation between internest distance and shelter rating $(r=.78$, $.001<P<.01$ ) existed for all habitats combined. Shelter was apparently a significant factor in the choice of nest location. In 1978, I removed cover adjacent to 12 nests in puffin habitat. Six pairs abandoned the nest sites altogether, and the other six reestablished new nests adjacent to nearby cover.

\section{Factors contributing to chick survival}

Two variables appeared to contribute significantly to chick survival in all three habitats. One was laying date, which was strongly negatively correlated with chick survival, i.e., chicks from early laid eggs had a higher survival rate. The other was growth rate, which was positively correlated with chick survival in most cases and was also negatively correlated with laying date. Other variables were only rarely significantly correlated with chick survival when growth rate and laying date were held constant.

In 1977 in rocky habitat, survival was affected by growth rate with laying date held constant $(r=.3394$, $P<.001)$. In 1978, chick survival was significantly correlated with laying date $(r=.4287, P<.001)$. In 1978 , chick survival was significantly correlated with laying date with growth rate held constant $(r=.2618$, $.01<P<.05$ ), and laying date was correlated with growth rate $(r=.2291, .01<P<.05)$. In puffin habitat in 1977 , growth rate $(r=.2795, .001<P<.01)$, and laying date $(r=.3560, .01<P<.05)$, and nest shelter $(r=.2120, .01<P<.05)$ were also correlated with chick survival with laying date, growth rate, and each other held constant.

In meadow habitat in 1977 , chick survival was strongly correlated with growth rate $(r=.3844$, $.001<P<.01)$, and growth rate was related to laying

TABLE 8. Growth rates of Herring Gull chicks on Great Island.

\begin{tabular}{clcc}
\hline \hline Year & Habitat & $(n)$ & $\begin{array}{c}\text { Growth rate } \\
\text { from day 5 } \\
\text { to day 30 } \\
(\mathrm{g} / \mathrm{d})\end{array}$ \\
\hline $1977^{*}$ & Puffin & $(111) \dagger$ & $28.99 \pm 7.03$ \\
& Rocky & $(93) \ddagger$ & $32.11 \pm 3.98$ \\
$1978^{*}$ & Meadow & $(79)$ & $26.27 \pm 6.53$ \\
& Puffin & $(119)$ & $31.38 \pm 4.57$ \\
& Rocky & $(89) \S$ & $33.39 \pm 4.72$ \\
& Meadow & $(80)$ & $31.68 \pm 5.43$ \\
\hline
\end{tabular}

* Differences among habitats significant at .05 level (ANOVA).

$\dagger \mathrm{P}>\mathrm{M}$ at .01 level (SNK).

$\ddagger \mathbf{R}>\mathbf{P}, \mathbf{M}$ at .01 level (SNK).

$\S \mathrm{R}>\mathrm{M}$ at .05 level $\mathrm{R}>\mathrm{P}$ at .01 level (SNK). 

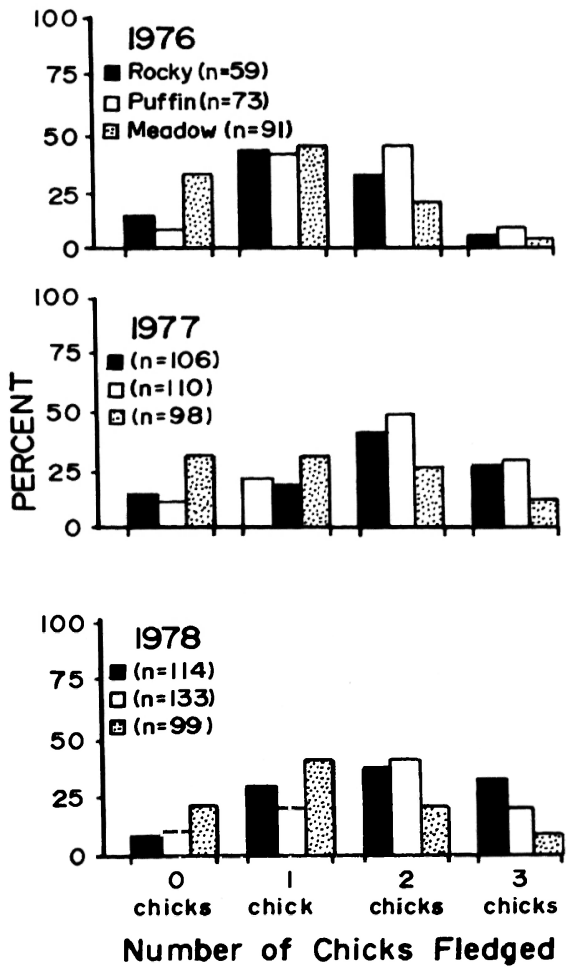

Fig. 4. Number of chicks fledged per nest in all three habitats on Great Island during 1976-1978.

date $(r=.7430, P<.001)$. In 1978 , both growth rate $(r=.4024, P<.001)$ and laying date $(r=.3194$, $.01<P<.05$ ) affected chick survival when the other was held constant, and the two were strongly related $(r=.5381, P<.001)$. Also, in meadow habitat, there were significant differences in laying date between chicks that died and those that survived to fledging. In 1977, chicks that survived to fledge hatched from eggs which were laid $6.2 \mathrm{~d}$ earlier on average (.001 $<P<.01$ by ANOVA). In 1978, chicks that fledged hatched from eggs laid $5 \mathrm{~d}$ earlier $(.001<P<$ .01 by ANOVA). This suggests that there was a significant advantage to early breeding in meadow habitat.

Although growth rate and the date of egg-laying appeared to be the principal factors affecting chick survival, a significant difference remained among habitats, even when the effects of these variables had been removed using analysis of covariance. Distance between nests accounted for some of this difference in 1978, when chicks from nests that were close together had a higher survival rate on average. The remaining effects, however, were probably due to differences in the habitats themselves, and in the behavior and attributes of the adult gulls which bred in those habitats (see Discussion and Pierotti 1979 for details).

\section{Chick mortality}

It appears that crowding and intraspecific aggression in rocky habitat produce some chick mortality. Of 63 chicks found dead in rocky habitat over $3 \mathrm{yr}, 58 \mathrm{had}$ apparently been killed by neighbors (heads were pecked, bloody, and often denuded of feathers), 4 died of an unknown disease which resembled pneumonia, and 1 was found wedged in a deep crack between rocks. Another factor which may have contributed to chick mortality was disturbance by me and my assistants, which would have been more serious in rocky habitat, where nests are closer together and there are fewer good hiding-places for chicks. As a result, chicks fleeing from me would have had a reduced

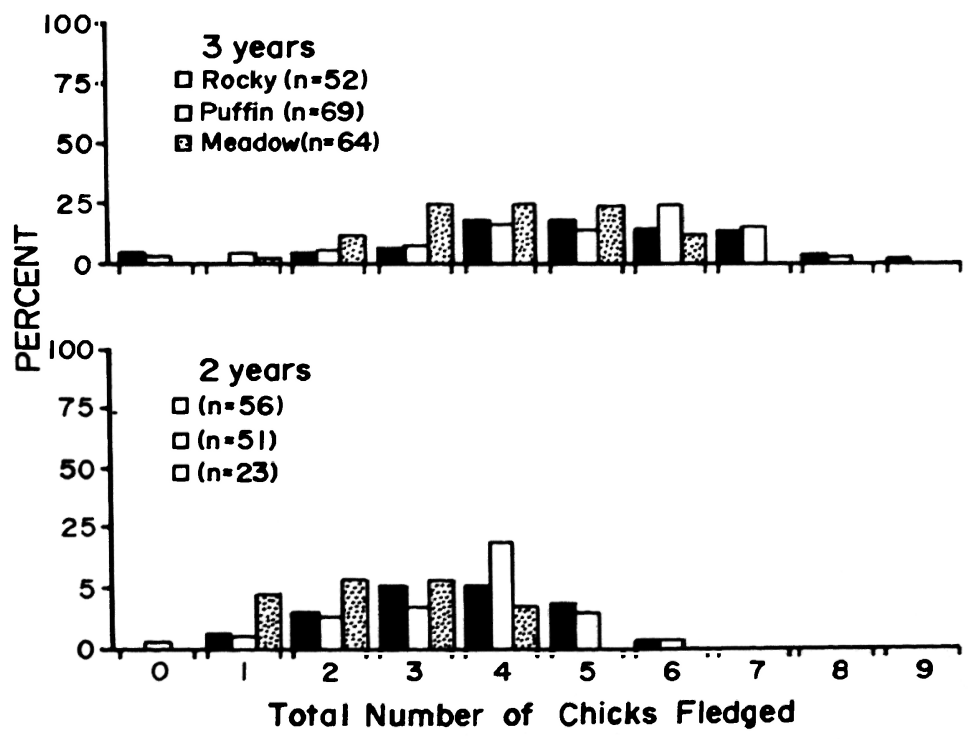

Fig. 5. Total number of chicks fledged per nest in all three habitats on Great Island (top: nests monitored during 1976-1978; bottom: nests monitored only during 1977-1978). 
TABLE 9. Nest-spacing and shelter of Herring Gull nests on Great Island. Sample sizes given in parentheses.

\begin{tabular}{lccc}
\hline & \multicolumn{2}{c}{ Mean internest distances $(\mathrm{m})$} & \\
\cline { 2 - 4 } Habitat & $1976 \ddagger$ & $1978 \ddagger$ & Shelter rating*, $\dagger$ \\
\hline Rocky & $4.14 \pm 0.68(67) \S$ & $3.97 \pm 0.50(120) \S$ & $13.49 \pm 1.92(120)$ \\
Puffin & $9.06 \pm 1.96(71)$ & $7.89 \pm 2.64(141)$ & $5.71 \pm 3.77(141)$ \\
Meadow & $7.10 \pm 1.40(90)^{\prime \prime}$ & $5.99 \pm 0.95(95)^{\|}$ & $6.20 \pm 3.86(95)$ \\
\hline
\end{tabular}

* See Table 10 for definition.

$\dagger$ Differences among habitats significant at .001 level $\left(\chi^{2}\right.$ test).

$\ddagger$ Differences among habitats significant at .001 level (ANOVA).

$\S \mathrm{R}<\mathrm{P}, \mathrm{M}$ at .01 level (SNK).

" $\mathrm{M}<\mathrm{P}$ at .01 level (SNK).

chance of returning to their natal territory (Hunt and McLoon 1975, Hunt and Hunt 1976). There was an increase in number of chicks fledged per nest in each habitat over the 3 yr of the study (with the exception of puffin habitat in 1978). I attribute this result to acclimation to disturbance on the part of the gulls. In an attempt to determine the magnitude of this disturbance, one study plot in each habitat was used as a control in 1977 and 1978. In these plots, chicks were not weighed after hatching. Only one of these control plots, in puffin habitat in 1977, had the highest breeding success for its habitat.

The apparent reason that Herring Gulls in meadow habitat experienced lower hatching and fledging success (Figs. 3, 4, and 5) was that this habitat was the preferred nesting habitat of Great Black-backed Gulls. This species has been reported to be a predator upon the eggs and young of Herring Gulls (Harris 1965, Erwin 1971), and this was true on Great Island as well. Of 97 dead Herring Gull chicks found in meadow habitat over $3 \mathrm{yr}, 92$ were found dead around the nests of Great Black-backed Gulls (only 42 of these chicks could be recognized by band numbers). In fact, chick survival in meadow habitat may be far lower than is indicated because many chicks that disappeared at $\approx 7$ wk of age and were not found dead were recorded as fledged, when they may have been killed and eaten by Great Black-backed Gulls.

\section{Female quality and egg production}

The egg production experiment conducted in 1978 was designed to find out whether female gulls in the three habitats had different abilities to acquire and mobilize energy. The hypothesis was that females that were best at either acquiring or mobilizing energy would produce the most eggs in the shortest period of time.

Female gulls in rocky habitat produced the most eggs on average $(7.0 \pm 2.5$ compared with $4.2 \pm 2.5$ eggs per female in both puffin and meadow habitats: Fig. 6a). Females in rocky habitat also initiated their clutches earlier in the breeding period, with a mean starting date of 15 May, compared with 19 May in meadow habitat and 20 May in puffin habitat. Females in rocky habitat also laid their eggs over the shortest period of time, as indicated by egg-laying patterns (Fig. 6b).

There were few significant differences in overall egg dimensions among habitats (Table 11). Eggs laid in both rocky and puffin habitats were heavier than those laid in meadow habitat. In yolk, albumin, and shell masses, eggs laid in rocky habitat were significantly heavier than eggs laid in meadow habitat, although not heavier than those laid in puffin haibtat.

\section{Discussion}

Although puffin habitat constituted $>60 \%$ of the habitat used for nesting by Herring Gulls (Larus argentatus) on Great Island, it contained $25 \%$ fewer nests than would have been expected if gulls settled in habitats at random. Meadow habitat contained about as many pairs as would be predicted by random settling. As a result, rocky habitat contained more than twice as many pairs as expected from random dispersion. This result suggests that rocky habitat is the preferred nesting habitat of Herring Gulls on Great Island, because gulls settle in this habitat even though it is crowded, rather than in other habitats where space

TABLE 10. Determination of shelter ratings. Prevailing winds on Great Island during the seabird-breeding period are southerlies, followed by northerlies, westerlies, and easterlies in descending order of importance. Thus, shelter ratings were determined by noting from which directions a nest was sheltered.

\begin{tabular}{lc}
\hline \hline Direction sheltered from & Shelter rating \\
\hline none & 0 \\
E only & 1 \\
W only & 2 \\
N only & 3 \\
S only & 4 \\
E, W only & 5 \\
E, N only & 6 \\
W, N only & 7 \\
E, S only & 8 \\
W, S only & 9 \\
N, S only & 10 \\
E, W, N only & 11 \\
E, W, S only & 12 \\
E, N, S only & 13 \\
W, N, S only & 14 \\
E, W, N and S & 15 \\
\hline
\end{tabular}




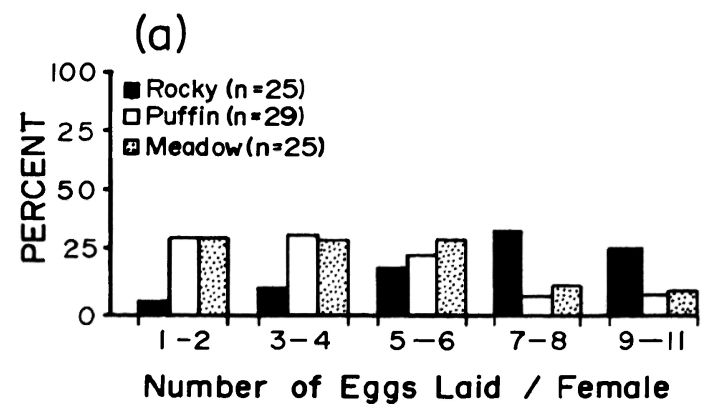

(b)

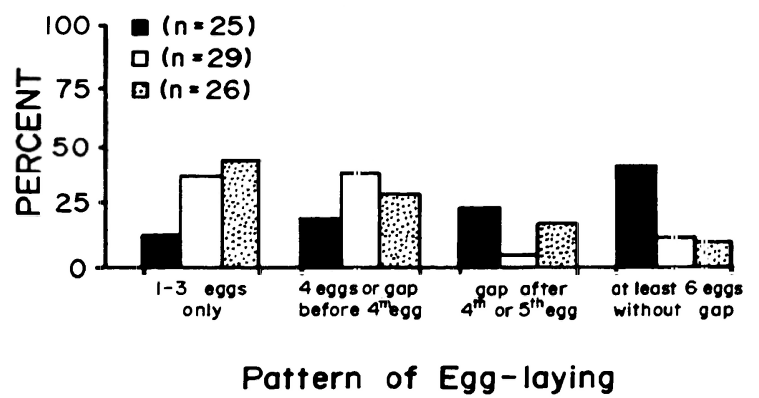

FIG. 6. Results of egg-production (egg removal) experiments: (a) number of eggs laid per female in all three habitats during 1979 breeding season; (b) pattern of egg laying in all three habitats (see Methods).

is more available. Although rocky habitat is spatially more heterogeneous, and certainly contains more area than two-dimensional measurements indicate, internest distances in this habitat were significantly smaller than in the other two habitats. This further suggests that gulls are willing to nest more densely in rocky habitat. In studies on the closely related Western Gull (Larus occidentalis) and Glaucous-winged Gulls (Larus glaucescens) (Hunt and McLoon 1975, Hunt and Hunt 1976), it has been shown that gull chick survival is positively related to territory size. Therefore, there are probably strong pressures influencing Herring Gulls to settle in rocky habitat, where territory sizes must be small because of crowding.

In each year, gulls nesting in meadow habitat had the lowest mean clutch size, but the differences be-
TABLE 12. Summary of the breeding performances of Herring Gulls on Great Island, Newfoundland.

\begin{tabular}{lcccc}
\hline \hline $\begin{array}{l}\text { Year and } \\
\text { habitat }\end{array}$ & $\begin{array}{c}\text { Number } \\
\text { of eggs } \\
\text { laid }\end{array}$ & $\begin{array}{c}\text { Hatching } \\
\text { success* }\end{array}$ & $\begin{array}{c}\text { Fledging } \\
\text { success } \dagger\end{array}$ & $\begin{array}{c}\text { Breeding } \\
\text { success } \ddagger\end{array}$ \\
\hline 1976 & & & & \\
$\quad$ Rocky & 161 & 0.752 & 0.645 & 0.484 \\
Puffin & 163 & 0.804 & 0.878 & 0.706 \\
Meadow & 192 & 0.766 & 0.639 & 0.489 \\
1977 & & & & \\
Rocky & 307 & 0.788 & 0.777 & 0.612 \\
Puffin & 364 & 0.651 & 0.869 & 0.566 \\
Meadow & 245 & 0.678 & 0.705 & 0.478 \\
1978 & & & & \\
Rocky & 310 & 0.748 & 0.909 & 0.681 \\
Puffin & 366 & 0.787 & 0.847 & 0.667 \\
Meadow & 235 & 0.715 & 0.750 & 0.536 \\
\hline
\end{tabular}

* Number of eggs hatched per egg laid.

$\dagger$ Number of chicks fledged per egg hatched.

$\ddagger$ Number of chicks fledged per egg laid.

tween rocky and puffin habitats were insignificant. The results in hatching success (Table 12) show no general pattern. In 1976, gulls breeding in puffin habitat had the highest fledging and breeding success, although the data from that season were somewhat incomplete. In 1977 and 1978, gulls in rocky habitat had the highest breeding success, although the differences are not great (Table 12).

Despite the general absence of significant differences in clutch size and the number of eggs hatched per nest, birds nesting in rocky habitat did lay their eggs significantly earlier than birds in the other habitats in 1977. It has been suggested (D. N. Nettleship, personal communication) that gulls breeding in puffin habitat may delay egg-laying so that their chicks emerge around the time that Atlantic Puffin eggs hatch in late June and early July (Nettleship 1972). Gulls could then provision their chicks with food stolen from breeding adult puffins. However, other results from my study have indicated that gulls breeding in puffin habitat do not depend heavily upon puffins as a food source (Pierotti 1979). In addition, early laying dates have been shown to be positively related to chick survival and growth rate in all three habitats. Therefore,

TABLE 11. Egg production experiment (egg dimensions).

\begin{tabular}{lccccccc}
\hline \hline Habitat & $(n)$ & $\begin{array}{c}\text { Length } \\
(\mathrm{mm})\end{array}$ & $\begin{array}{c}\text { Breadth } \\
(\mathrm{mm})\end{array}$ & $\begin{array}{c}\text { Mass } \\
(\mathrm{g})^{*}\end{array}$ & $\begin{array}{c}\text { Yolk } \\
(\mathrm{g}) \dagger\end{array}$ & $\begin{array}{c}\text { Albumin } \\
(\mathrm{g}) \ddagger\end{array}$ & $\begin{array}{c}\text { Shell } \\
(\mathrm{g})^{*}\end{array}$ \\
\hline Rocky & $(174)$ & $70.2 \pm 8.2$ & $48.4 \pm 5.5$ & $91.8 \pm 13.18$ & $22.0 \pm 3.98$ & $58.0 \pm 11.08$ & $7.1 \pm 1.41$ \\
Puffin & $(121)$ & $70.2 \pm 9.6$ & $48.3 \pm 6.5$ & $91.5 \pm 14.28$ & $21.5 \pm 4.58$ & $57.6 \pm 12.38$ & $6.9 \pm 1.3$ \\
Meadow & $(109)$ & $69.1 \pm 10.2$ & $47.3 \pm 6.7$ & $\mathbf{8 7 . 5} \pm 14.9$ & $19.3 \pm 6.3$ & $52.6 \pm 17.1$ & $6.5 \pm 2.1$ \\
\hline
\end{tabular}

* Difference among habitats significant at .05 level (ANOVA).

$\dagger$ Difference among habitats significant at .001 level (ANOVA).

$¥$ Difference among habitats significant at .025 level (ANOVA).

$\& \mathrm{R}, \mathrm{P}>\mathrm{M}$ at .05 level (SNK).

" $\mathrm{R}>\mathrm{M}$ at .05 level (SNK). 
there is an apparent advantage to laying eggs as early as possible.

Differences observed in the breeding biology of Herring Gulls between 1977 and 1978 were probably a result of two factors. First, the winter of 1977-1978 was exceptional in its severity along the entire Eastern Seaboard. Stormy weather continued into May in Newfoundland, and this may have affected the foraging ability of gulls. Gulls are primarily dippers, surface seizers, or plunge divers when feeding at sea (Ashmole 1971), and stormy weather would reduce their ability to perform these actions. Several investigators have demonstrated that rough weather and stormy seas reduce the ability of seabirds to obtain food (Dunn 1973, Birkhead 1977, Lloyd 1979). In 1978 , the weather in Newfoundland was much milder in May, with higher temperatures, lower average wind speeds, and reduced precipitation (Environment Canada 1977-1978)

The second factor that may have affected Herring Gull breeding biology was the availability of capelin (Mallotus villosus), a principal food source of seabirds in Newfoundland (Winters and Carscadden 1978). Conversations with fishermen at St. John's, Petty Harbour, Bay Bulls, Bauline East, and Ferryland indicated that the occurrence of capelin was very sporadic and well below normal around the Avalon Peninsula during 1977, whereas in 1978, capelin were present in the area in large numbers. In addition, fisheries research statistics (ICNAF 1978) indicate that inshore capelin stocks, which have been in decline since the mid-1970's, increased markedly in 1978. The bad weather in May and June 1977 may have affected capelin spawning, which generally occurs in inshore waters of the Avalon Peninsula during this period (Templeman 1948, Pitt 1958, Carscadden and Miller 1979).

If gulls experienced difficulty in foraging during spring 1977, this could account for the reduced size of eggs in that year. In all dimensions except egg breadth, eggs were significantly larger in 1978 than in 1977 (Table 5). The only significant difference among habitats, however, was that eggs laid in rocky habitat in 1978 were heavier than those in the other habitats. As chicks in rocky habitat were also significantly heavier at most ages during the nestling period, gulls nesting in rocky habitat may be more efficient at foraging. This idea is supported by the results of the egg production experiment, for female gulls in rocky habitat produced more eggs over shorter periods of time than did females in the other habitats.

Despite their apparent greater ability to acquire and mobilize energy, gulls in rocky habitat did not fledge more chicks than gulls in puffin habitat. In fact, in 1976 and 1977, gulls in puffin habitat actually fledged more chicks per nest, although the difference was significant only in 1976. Also, over the $3 \mathrm{yr}$ of the study there was no significant difference in the total number of chicks fledged per pair in rocky and puffin habitat (Fig. 5).

At this point, it should be recalled that chicks fledging from rocky habitat grew at faster rates and were significantly heavier than chicks fledging from the other habitats. There is evidence from other studies of gull breeding biology that early hatching or fastergrowing chicks may survive better. Results from largescale bandings of Herring Gull chicks have shown that early hatching chicks have a higher survival rate (Nisbet and Drury 1972, Parsons et al. 1976), and in the present study chicks in rocky habitat hatched significantly earlier in 1977 , a year in which food was apparently scarce. In addition, Spaans (1971) has shown in Herring Gulls that when food is less available, early hatched chicks grow at a faster rate than do latehatched chicks. Working on related species, Hunt and Hunt (1976) have shown that heavier chicks have a higher survival rate, and Briggs (1977) has shown that early hatched gull chicks tend to be larger and socially dominant over smaller and later-hatched chicks at food sources during the winter. It is generally agreed that the first winter is crucial in determining survival of young gulls, because this is when they suffer their highest rate of mortality (Kadlec and Drury 1968, Spaans 1971, Coulter 1975, Briggs 1977). In fact, mortality during this period may be higher than during the 1st wk of life, which is considered to be the time when the highest mortality rate occurs in most species (compare Kadlec and Drury 1968:Table 22 with Hunt and Hunt 1976:Table 2). Because growth rate was shown to be positively correlated with prefledging survival of chicks in this study, gulls nesting in rocky habitat may produce more offspring that survive the first winter, even though they may not fledge more chicks at the end of the breeding period.

The rocky marine terraces also appear to be the original nesting habitat for Herring Gulls on Great Island, for this was the habitat initially occupied by Herring Gulls when they appeared on Great Island during the late 1940's (L. M. Tuck, personal communication). In addition, many Herring Gulls attempted to settle in rocky habitat during this study, but were prevented from doing so by crowding and the aggression of resident birds (Pierotti 1979). There appeared to be very few available nest sites in rocky habitat, and this may provide an explanation for the apparently contradictory results in fledging success. If rocky habitat is saturated, as appears to be the case, then gulls which are unable to establish themselves in rocky habitat may instead settle in puffin or meadow habitat where they could produce as many or more offspring, than pairs in rocky habitat could.

The overall picture which emerges, then, is that Herring Gulls nesting in rocky habitat are probably competitively superior to gulls nesting in the other habitats. Birds nesting in puffin habitat are far more successful at breeding than birds in meadow habitat 
(Table 12), although this does not appear to involve any competitive exclusion, because puffin habitat is undersaturated and appears to be readily invadable by nonestablished pairs. Socially induced chick mortality is low in puffin habitat because nests are spaced far apart. There are only a few Great Black-backed Gulls in puffin habitat so predation is minimal, and there are abundant hiding places for chicks in Atlantic Puffin burrows. As a result, even disturbance by humans is minimized, as chicks are unlikely to leave their natal territories. In addition, Atlantic Puffins may be exploited as a source of food. This may explain the observation that despite lower hatching masses, chicks in puffin habitat were as heavy or heavier than chicks in rocky habitat at 5 and $10 \mathrm{~d}$ of age in 1977 (Tables 7, 8, and 9). Puffins bring in small capelin (average mass: 12-13 g; Nettleship 1972) which are ideal food for young gull chicks. As food appeared to be scarce during this period in 1977, Puffin-robbing gulls may have been temporarily more successful at obtaining provisions for their chicks. However, in the long run, this food supply proved inadequate for large chicks $(>500 \mathrm{~g})$, so chicks in rocky habitat overtook the chicks in puffin habitat by the age of $15 \mathrm{~d}$.

A final argument which supports the contention that rocky habitat is the preferred (and possibly ancestral) habitat of Herring Gulls involves the cryptic coloration of Herring Gull chicks, which is gray with darker markings. This coloration is excellent camouflage in rocky habitat, but against the green of puffin slopes and meadows, the chicks can be easily spotted. (See Fig. 1.)

Results of this study support the theoretical predictions of Fretwell and Lucas (1970), which suggested that as density increases in preferred habitat, the fitness of individuals in that habitat should decline until the expected fitness is as high or higher in a less-preferred habitat. At the same time, counterevidence is provided to refute Brown's (1969) assertion that there is always a cost in fitness associated with breeding in a habitat which is not the preferred one. These results also overcome Partridge's (1978) objection that differences in breeding success among habitats may simply result from phenotypic superiority of individuals which succeed in nesting in a preferred habitat. Herring Gulls in rocky habitat appear to be phenotypically superior, yet on a year-to-year basis, they produce no more fledged chicks than gulls which nest in an apparently less-preferred habitat, even though more of the chicks raised in rocky habitat may survive to breed.

In fact, if we assume a high degree of philopatry, most recruitment to the Great Island population probably comes from birds raised in less preferred habitat. There are more than twice as many pairs breeding in puffin habitat as there are in rocky habitat. As the number of chicks fledged per pair is essentially the same in these two habitats, survival until reproductive age of birds from rocky habitat would have to be more than double that of birds from puffin habitat for recruitment to be higher from rocky habitat. Very little recruitment probably comes from meadow habitat, because these birds are not even producing enough offspring to maintain a stable population (assuming that this requires $10 \%$ annual adult mortality, $50 \%$ survival from fledging to reproductive age, and four reproductive seasons; Kadlec and Drury 1968).

However, long-term banding studies of Herring Gulls have indicated that although many individuals return to their natal colony to breed, many others settle in completely different areas (Kadlec and Drury 1968, Spaans 1971, Parsons et al. 1976). It is not known if there is a tendency, either innate or learned, for gulls to settle in the type of habitat in which they were raised. However, as Herring Gulls are known to be extremely flexible in their choice of nest sites (Tinbergen 1960, Graham 1975), it is unlikely that such preferences exist. What is more likely is that preferences for specific habitats, such as rocky marine terraces, exist. Only when these habitats are fully occupied do gulls settle in other habitats.

These results are also of interest with regard to the hypotheses concerning the relationship of territoriality to distribution reviewed by Fretwell and Lucas (1970). These hypotheses are: (1) that territoriality provides a means of density assessment whereby individuals can avoid heavily populated habitats (Kluyver and Tinbergen 1953, Wynne-Edwards 1962), (2) that territoriality is a density-limiting device whereby population growth rates can be affected (Brown 1964), and (3) territorial behavior has evolved only to space individuals within a habitat (Lack 1966).

In Herring Gulls it appears that, under certain circumstances, territoriality may act as a density-assessment mechanism because it is apparent that some birds are prevented from establishing in preferred habitat and choose to settle in less-preferred areas. However, in the preferred habitat, territoriality may act as a density-limiting mechanism through socially induced mortality. In the less-preferred habitats, where internest distances are large, territoriality may serve only to space individuals. It appears, therefore, that none of these hypotheses are mutually exclusive and as a result, the functions of territory in Herring Gulls are probably highly flexible.

\section{ACKNOWLEDGMENTS}

I thank Drs. R. G. B. Brown, R. W. Doyle, J. C. Fentress, and E. L. Mills for their comments and encouragement during this study. Dr. David Nettleship of the Canadian Wildlife Service provided funding and constant helpful comments and support during the study, and helped to develop the initial questions investigated during the field work. I also thank the Reddick family of Bauline East, Newfoundland, for their hospitality and logistic support in Newfoundland. I thank B. Johnson, I. Goudie, and Dr. L. M. Tuck of the Canadian Wildlife Service in St. John's, Newfoundland, for logistic support, and Bruce, Anne, Glen, and Carl Johnson for their 
friendship and hospitality in St. John's. I also thank Dr. Steven Fretwell and an anonymous reviewer for their comments.

S. D. Johnson and C. M. Friesen provided valuable help in the collection of data under conditions that were often trying. The staff of the Biology Department and the Computer Centre at Dalhousie provided aid in both word and data processing. Support at Dalhousie was provided by a fellowship from the I. W. Killam Foundation.

Finally, I thank Ian McLaren for his patient help and excellent supervision during my term at Dalhousie. I dedicate this research to the memory of Dr. Les Tuck, one of the pioneers of seabird research both in Newfoundland and in Eastern Canada.

\section{Literature Cited}

Ashmole, N. P. 1971. Sea bird ecology and the marine environment. Pages 224-286 in D. S. Farner and J. R. King, editors. Avian biology. Volume I. Academic Press, New York, New York, USA.

Beer, C. G. 1962. Incubation and nest-building behaviour of the Black-headed Gull II. Incubation behaviour in the laying period. Behaviour 19:283-304.

Birkhead, T. R. 1977. Effects of sea conditions on rates at which guillemots feed chicks. British Birds 69:490-492.

Briggs, K. T. 1977. Social dominance in young Western Gulls: its importance in survival and dispersal. Dissertation. University of California, Santa Cruz, California, USA.

Brown, J. L. 1964. The evolution of diversity in avian territorial systems. Wilson Bulletin 76:160-169.

1969. Territorial behavior and population regulation in birds. Wilson Bulletin 81:293-329.

Brown, R. G. B., D. N. Nettleship, P. Germain, C. E. Tull, and T. Davis. 1975. Atlas of eastern Canadian seabirds. Canadian Wildlife Service Publication, Canadian Wildlife Service, Ottawa, Ontario, Canada.

Carscadden, J. E., and D. S. Miller. 1979. Biological aspects of capelin and a sequential capelin abundance model for the division 3LN0 stock. Research Document 79/11/33, International Commission for the Northwest Atlantic Fisheries, Dartmouth, Nova Scotia, Canada.

Coulter, M. C. 1975. Post-breeding movements and mortality in the Western Gull, Larus occidentalis. Condor 77:243-249.

Dunn, E. K. 1973. Changes in fishing ability of terns associated with wind-speed and sea surface conditions. Nature 244:520-521.

Environment Canada 1977-1978. Monthly record: meteorological observations in eastern Canada. Canadian Government Document, Department of Atmosphere and Environment, Ottawa, Ontario, Canada.

Erwin, R. M. 1971. The breeding success of two sympatric gulls, the Herring Gull and the Great Black-backed Gull. Wilson Bulletin 83:151-158.

Fretwell, S. D., and H. L. Lucas, Jr. 1970. On territorial behavior and other factors influencing habitat distribution in birds. I. Theoretical development. Acta Biotheoretica 19: $16-36$.

Graham, F., Jr. 1975. Gulls, a social history. Random House, New York, New York, USA.

Harris, M. P. 1965. The food of some Larus gulls. Ibis 107:43-53.

Hunt, G. L., Jr., and M. W. Hunt. 1976. Gull chick survival: the significance of growth rates, timing of breeding, and territory size. Ecology 57:62-75.

Hunt, G. L., Jr., and S. C. McLoon. 1975. Activity patterns in gull chicks in relation to feeding by parents: their potential significance for density-dependent mortality. Auk 92:523-527.

International Commission for the Northwest Atlantic Fisheries. 1978. Annual Report 28, ICNAF, Dartmouth, Nova Scotia, Canada.

Kadlec, J. A., and W. H. Drury. 1968. Structure of the New England Herring Gull population. Ecology 49:644-676.

Kluyver, N. N., and L. Tinbergen. 1953. Territory and the regulation of density in titmice. Archives Neerlandaises de Zoologie 10:265-289.

Lack, D. 1966. Population studies of birds. Clarendon Press, Oxford, England.

Lloyd, C. S. 1979. Factors affecting breeding of Razorbills, Alca torda, on Skokholm. Ibis 121:165-176.

Nettleship, D. N. 1972. Breeding success of the Common Puffin (Fratercula arctica L.) on different habitats at Great Island, Newfoundland. Ecological Monographs 42:239-268. . 1976. Census techniques for seabirds of arctic and eastern Canada. Occasional Paper Number 25, Canadian Wildlife Service, Ottawa, Ontario, Canada.

Nisbet, I. C. T., and W. H. Drury. 1972. Post-fledging survival in Herring Gulls in relation to brood size and date of hatching. Bird-Banding 43:161-173.

Paludan, K. 1951. Contribution to the breeding biology of Larus argentatus and L. fuscus. Videnskabelige Meddelelser fra Dansk Naturhistorisk Forening 114:1-218.

Parsons, J. 1976. Factors determining the number and size of eggs laid by the Herring Gull. Condor 78:481-492.

Parsons, J., G. Chabrzyk, and N. Duncan. 1976. Effects of hatching date on post-fledging survival in Herring Gulls. Journal of Animal Ecology 45:667-675.

Partridge, L. 1978. Habitat selection. Pages 351-376 in J. R. Krebs and N. B. Davies, editors. Behavioural ecology. Sinauer, Sunderland, Massachusetts, USA.

Pierotti, R. 1979. The reproductive behavior and ecology of the Herring Gull in Newfoundland. Dissertation. Dalhousie University, Halifax, Nova Scotia, Canada.

Pitt, T. K. 1958. Distribution, spawning, and racial studies of the capelin, Mallotus villosus (Muller) in the offshore Newfoundland area. Journal of the Fisheries Research Board of Canada 15:275-293.

Salomonsen, F. 1939. Oölogical studies in gulls. 1. Egg-producing powers of Larus argentatus. Pontificiae Dansk Ornithologisk Forenings Tidsskrift 33:113-133.

Sokal, R. R., and F. J. Rohlf. 1969. Biometry. W. H. Freeman, San Francisco, California, USA.

Spaans, A. L. 1971. The feeding ecology of the Herring Gull, Larus argentatus, in the northern part of the Netherlands. Ardea 59:1-188.

Templeman, W. 1948. The life history of the capelin (Mallotus villosus) in Newfoundland waters. Research Bulletin 17, Newfoundland Laboratory, Newfoundland, Canada.

Tinbergen, N. 1960. The Herring Gull's world. Harper and Row, New York, New York, USA.

Winters, G. H., and J. E. Carscadden. 1978. Review of capelin ecology and estimation of surplus yield from predator dynamics. International Commission for the Northwest Atlantic Fisheries Research Bulletin 13:21-30.

Wynne-Edwards, V. C. 1962. Animal dispersion in relation to social behaviour. Hafner, New York, New York, USA. 